\title{
Male and female reproductive systems of Stolas conspersa (Germar) (Coleoptera, Chrysomelidae, Cassidinae)
}

\author{
Marianna V. P. Simões ${ }^{1}$ \\ ${ }^{1}$ Museu Nacional, Universidade Federal do Rio de Janeiro, Quinta da Boa Vista, São Cristovão, 20940-040 Rio de Janeiro - RJ, Brazil. \\ marianna_simoes@yahoo.com
}

\begin{abstract}
Male and female reproductive systems of Stolas conspersa (Germar) (Coleoptera, Chrysomelidae, Cassidinae). The male and female reproductive systems of Stolas conspersa (Germar, 1824) are described and illustrated for the first time. The male reproductive system shows no difference from the subfamily pattern, which is a tubular well-developed median lobe; "Y", "V" or T-shaped tegmen; reduced pygidium; internal sac membranous and tubular; flagellum generally well developed needle-like structured and gastral spiculum absent. However, the female differs from the pattern proposed for Stolas in two aspects: ovary with 28 ovarioles and a reduced ampulla with indistinct velum.
\end{abstract}

KEYWORDS. Genitalia; Mesomphaliini; morphology; Neotropical.

RESUMO. Sistema reprodutivo masculino e feminino de Stolas conspersa (Germar) (Coleoptera, Chrysomelidae, Cassidinae). O sistema reprodutivo do macho e fêmea de Stolas conspersa (Germar, 1824) são descritos pela primeira vez._Neste estudo, foi observado que o macho não diverge do padrão proposto para a subfamília, que é edeago tubular e bem desenvolvido; tégmen em forma de "Y", "V" ou "T"; pigídio reduzido; saco interno membranoso e tubular; flagellum geralmente bem desenvolvido, em forma de agulha e espículo gastral ausente. Por outro lado, o sistema reprodutor feminino diverge do padrão usual proposto para o gênero Stolas em dois aspectos: ovário com 28 ovaríolos e ampola reduzida com velum não distinto.

PALAVRAS-CHAVE. Genitália; Mesomphaliini; morfologia; Neotropical.

Reproductive systems are a traditional source of phylogenetic characters in entomology (Chaboo 2007). However, there were only a few papers concerning the genitalia morphology on a broad spectrum within the subfamily Cassidinae. Mann (1988) was the only paper on the comparative morphology in male genitalia in Cassidinae sensu lato and Swietojanska (2001) is the only large monograph of Cassidinae where structure of male genitalia was used as diagnostic character to all reviewed taxa within the tribe Aspidimorphini of the Oriental Region. Bordy \& Doguet (1987) proposed the female genitalia as an important character in classification of species groups in Cassidinae and recent studies on genitalia of some species have indicated a large diversity of spermathecal morphology (Rodriguez 1994a, b; Chaboo 2001; Borowiec \& Swietojanska 2001, Borowiec \& Skuza 2004; Borowiec \& Opalinska 2007; Borowiec \& Pomorska 2009).

The genus Stolas Billberg, 1820 is classified in the tribe Mesomphaliini Hope, 1840 and comprises 185 species which are distributed in the Neotropical region (Borowiec \& Swietojanska 2011). Stolas species are moderately large cassids, about 7-21 mm long. Sexual dimorphism is usually indistinct, many species are polymorphic in respect of dorsal pattern and polymorphic groups of species are partly difficult to identify (Borowiec \& Pomorska 2009). Only 11\% of the species present host plant record and they are usually associated with plants from families Convolvulaceae and Asteraceae (Borowiec \& Swietojanska 2011).
Borowiec \& Pomorska (2009) described and illustrated the spermathecae of seventy-two species, and divided Stolas into species groups based on its morphology. They concluded that spermathecae of externally similar species are often very similar and their diagnostic value is of little use, plus it was not observed any degree of complication of spermathecal structure.

In this paper the male and female reproductive systems of Stolas conspersa (Germar, 1824) are described and illustrated for the first time, aiming to bring some light to the reproductive system that has been generally neglected and considered to be unvarying in males or females.

\section{MATERIAL AND METHODS}

The two examined exemplars were collected by hand at the Parque Nacional do Itatiaia (PNI) at $1.200 \mathrm{~m}$, state of Rio de Janeiro, Brazil on 02.10.2010. The specimen identification was made by comparison with previously identified specimens from the MNRJ/UFRJ collection.

They were caught during copulation and taken to laboratory where oviposition occurred five days later. The specimens were kept alive for two more days and then left at the freezer to conserve the tissue. Integument structures were examined and illustrated using a Leica Mz 7.5 stereomicroscope and drawing tube. The specimens were fixed in $70 \%$ alcohol, and the genitalia were preserved in small vials with 
glycerine. These are deposited in the collection of the Museu Nacional, Universidade Federal do Rio de Janeiro.

Terminology generally follows Snodgrass (1935) and Chaboo (2007) with some male genitalia terms from Mann (1988) and some female genitalic terms from Rodriguez (1994b), Chaboo (2007) and Borowiec \& Opalinska (2007).

\section{RESULTS}

Male reproductive system (Figs. 1-6). Median lobe (Fig. 1) in a $90^{\circ}$ angle with tegmen, tubular, parallel-sided, neck constricted dorso-ventrally; basal orifice oval, margin explanate; apex flat small hood flanking the ostium; lower wall of ostium, differentially sclerotized into paired lateral plates. Internal sac weakly sclerotized, surface with spicules. Ejaculatory guide cross-like under dorsal view. Tegmen Yshaped (Figs. 2-3) edge of the aedeagus, with muscles com-
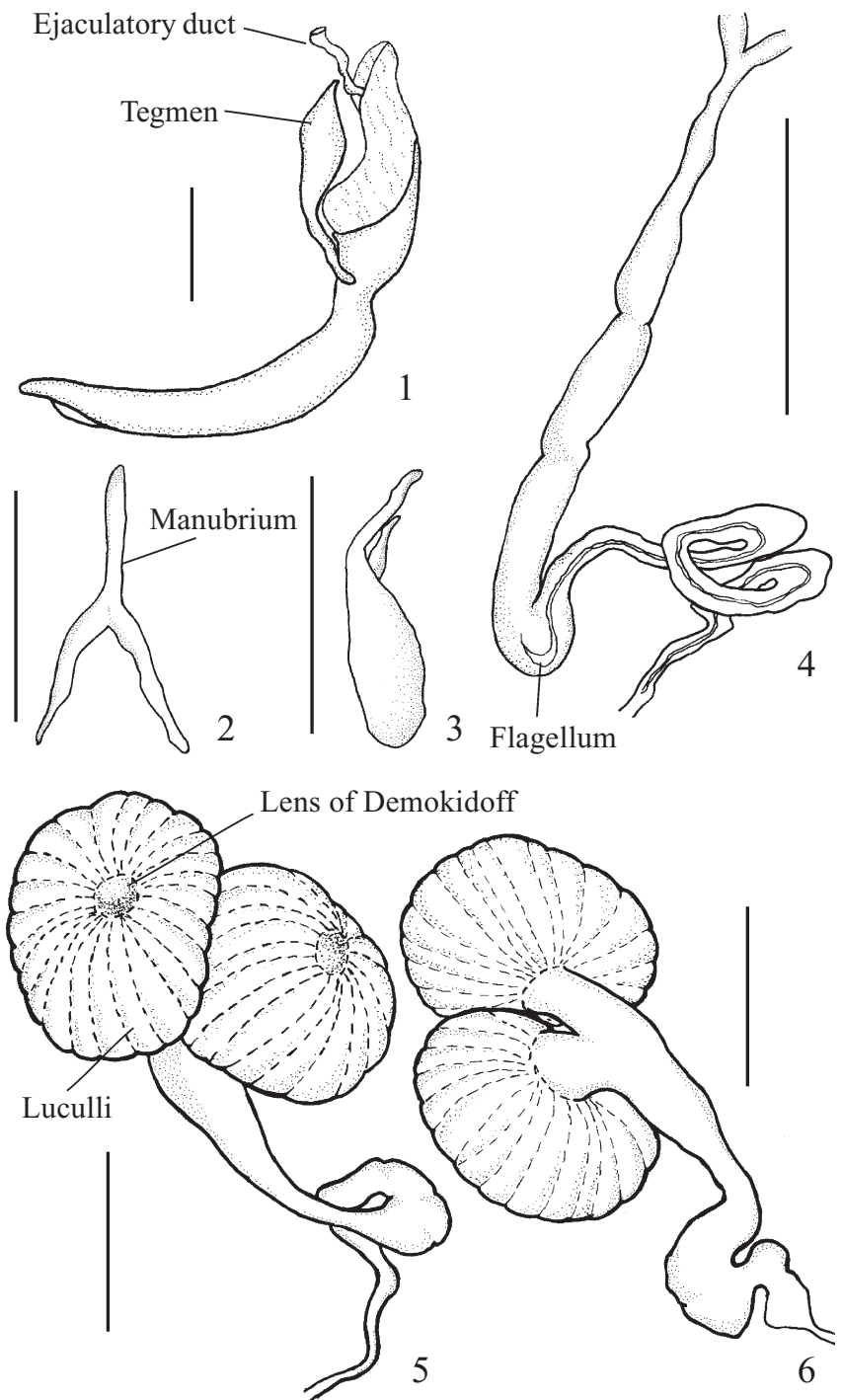

Figs. 1-6. Stolas conspersa, male reproductive system. 1, aedeagus; 2-3, tegmen, (2) dorsal and (3) lateral view; 4, seminal vesicle; 5-6, bilobed test, (5) dorsal and (6) ventral view. pleting the connection around the base; manubrium, as long as arms dorsally, laterally compressed, and lateral view about three times wider than in dorsal view, with rounded apex. Pygidium punctuate, with long and dense setae, base laterally with hook-shaped extentions, apex semioval. Ejaculatory duct long, about 12 times longer than aedeagus, coils loose proximally and tight distally. Flagellum feebly sclerotized, with a short distal hook. Seminal vesicle (Fig. 4) wide distally and tapered proximally with proximal portion deflexed into vas deferens. One pair of bilobed testes (Figs. 56 ), with around 20 distinct loculli around the Lens of Demokidoff. Accessory gland absent.

Female reproductive system (Fig. 7-13). Mature ovaries lie laterad of the alimentary canal, occupying almost the entire abdomen. Lateral oviduct with anterior end expanded to form a calyx, where seven pedicels of the ovarioles open. Pedicels with 2-3 branches (Fig. 8). Each ovary with 28 ovarioles. Lateral oviduct short and robust, about 2.5 times shorter than ovariole size. Bursa copulatrix rounded (Fig. 9), coated in thick muscle fibers. Each ovariole with pedicel, vitellarium, germinarium and terminal filament. The ovarioles were on the stage IV of development, with germinarium white, followed by three yellow creamy colored egg chambers showing completed vitellogenesis. Ovipositor (Fig. 10) on lateral view, with coxites "U" shaped and sclerotized, enlarged with dense and long distal setation and the other extremity acuminated; sclerotized sternite VIII (Fig. 13), with long and distal setation. Tergite IX (Fig. 10) with two short and transverse separated plates. Colleterial glands paired and bursiform, white colored. Spermatheca (Fig. 7) well-sclerotized, with muscle on inner margin, large vasculum with broad base and hook-shaped apex; receptacle simple, with distinguish chamber. Ampulla and velum indistinct. Ductus thin, long with stronger spiralization in basal and central part of the ductus than close to bursa copulatrix. Ductus and vasculum ratio 5:1. Gland elongate and basally positioned; duct and gland opening separately and directly into receptacle.

\section{DISCUSSION}

There is no previously description of the male reproductive system within the tribe, but the general aspect of the male genitalia of Stolas conspersa follows the pattern proposed to the subfamily by Mann (1988), which is a tubular well-developed median lobe; "Y", "V" or T-shaped tegmen; reduced pygidium; internal sac membranous and tubular and gastral spiculum absent. The tegmen is clearly similar to Glyphocassis trilineata (Hope) (Mann 1988: 126, figs. 7b, $8 \mathrm{~b}$ ), with median arm laterally compressed and the median lobe resembling that of Laccoptera nepalensis Boheman, 1855, (Mann 1988: 126, fig. 11b) with tubular, parallel-sided, neck-constricted, but glabrous, not showing row of short setae. The ejaculatory guide is quite similar to Laccoptera quadrimaculata (Thumberg) (Mann 1988: 126, fig. 11c) with a cross-like aspect. The internal sac surface of $S$. conspersa is armed with spicules. 

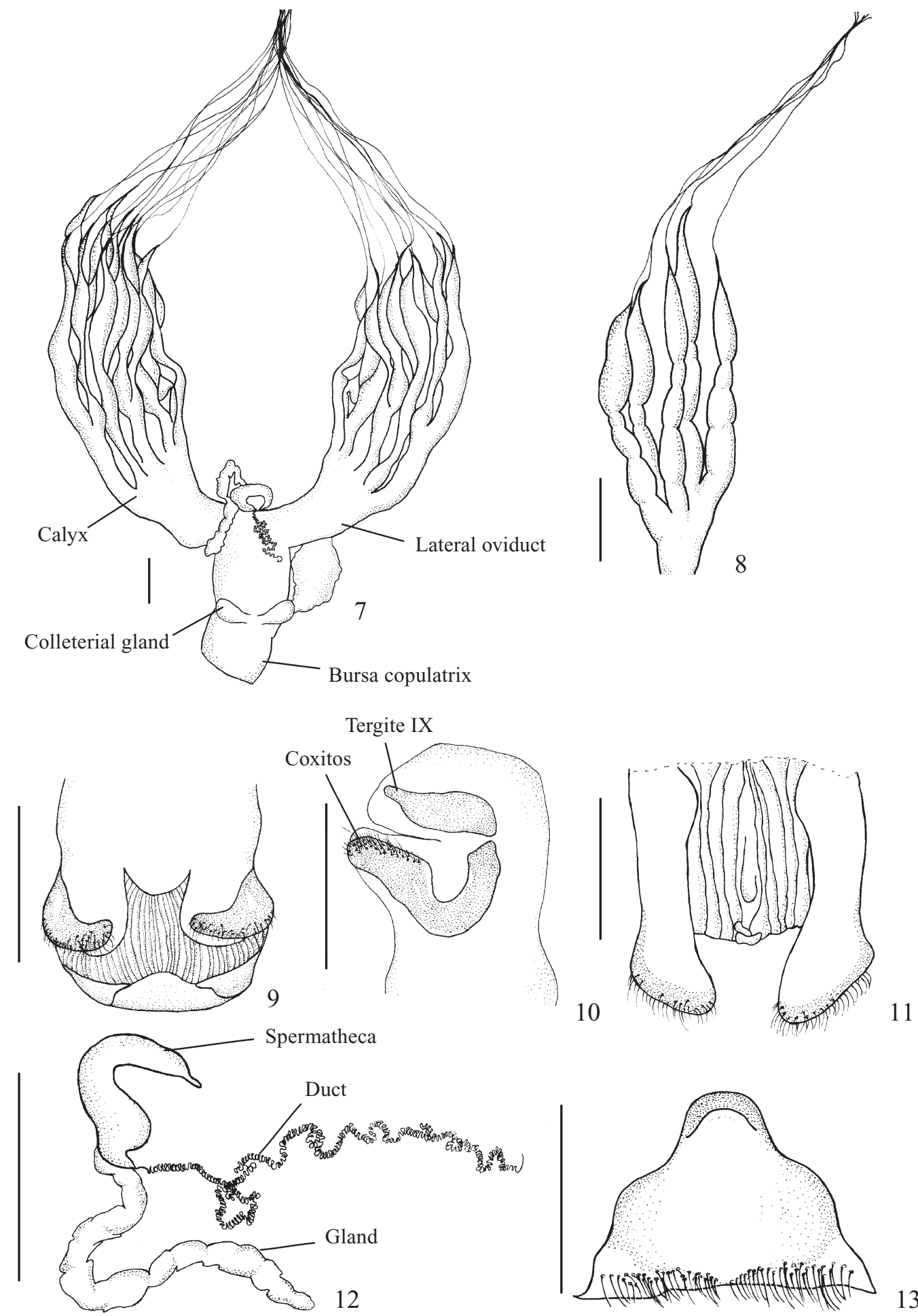

Figs. 7-13. Stolas conspersa, female reproductive system. 7, reproductive system; 8, pedicels divided into two or three branches; 9-10, bursa copulatrix, (9) ventral view and (10) lateral view showing tergite IX and coxites; 11, coxites; 12, spermatheca, spermathecal duct and gland; 13, sternite VIII.

The ovarioles studied here were of stage IV development, with the germinarium white, followed by three yellow creamy colored egg chambers showing completed vitellogenesis, according to Ganho \& Marinoni (2000). Each ovary contained 28 ovarioles; previously the number of cassidine ovarioles were described as ranging from 3 to 21 (Robertson
1961; Mann \& Singh 1979; Chaboo 2007). This variation might be consequence of environmental factors (Jolivet \& Verma 2002) or probably from the large size of $S$. conspersa.

Borowiec and Pomorska (2009) studied the structure of the spermathecae in the genus Stolas, and suggested seven groups of species. S. conspersa was not included in the analy- 
ses, however it was considered to be part of group VII, which shows the velum present, ampulla short, hardly marked, the ductus thin, very long and spiral, close to the bursa copulatrix and the spiral coils sometimes less dense than in the basal and central part of ductus. This study corroborates the position of $S$. conspersa within the group VII (Borowiec and Pomorska 2009: 218-219, figs. 53-64), differing only on the reduced ampulla with an indistinct velum, what may vary within the species.

\section{ACKNOWLEDGEMENTS}

I thank Marcela Monné (MNRJ/UFRJ) for comments on the manuscript. To Caroline Chaboo (Department of Ecology and Evolutionary Biology, University of Kansas) for comments on the manuscript and revision the English text. To Lech Borowiec (Zoological Institute, University of Wroclaw) and Caroline Chaboo for providing part of the bibliography. I would like to express my sincere thanks to anonymous reviewers for the critical comments on the manuscript and the financial support of a CNPq fellowship.

\section{REFERENCES}

Chaboo, C. S. 2001. Revision and Phylogenetic Analysis of Acromis Chevrolat (Coleoptera: Chrysomelidae: Cassidinae: Eugenysini). The Coleopterists Bulletin 55: 50-67.

Chaboo, C. S. 2007. Biology and phylogeny of the Cassidinae Gyllenhal sensu lato (tortoise and leaf-mining beetles) (Coleoptera: Chrysomelidae). Bulletin of the American Museum of Natural History 305: 1-250.

Bordy, B. \& Doguet, S. 1987. Contribution à la connaissance des Cassidinae de France. Etude de leur spermatheque (Coleoptera, Chrysomelidae). Nouvelle Revue d'Entomologie (N.S.) 4: 161-176.

Borowiec, L. \& M. Skuza. 2004. The structure of spermatheca in the genus Chelymorpha Chevrolat, 1837 (Coleoptera: Chrysomelidae: Cassidinae) and its taxonomic significance. Annales Zoologici 54: 439-451.

Borowiec, L. \& S. Opalinska. 2007. The structure of spermathecae of selected genera of Stolaini and Eugenysini (Coleoptera: Chrysomelidae: Cassidinae) and its taxonomic significance. Annales Zoologici 57: 463479.

Borowiec, L. \& J. Pomorska. 2009. The structure of the spermathecae of the genus Stolas (Coleopera: Chrysomelidae: Cassidinae: Mesomphaliini) and its taxonomic significance. Annales Zoologici 59: 201-221.

Borowiec, L. \& Swietojanska, J. 2001. Revision of Cassida litigiosa group from southern Africa (Coleoptera: Chrysomelidae: Cassidinae). Annales Zoologici 51: 153-184.

Borowiec, L. \& J. Swietojanska. 2011. World catalog of Cassidinae. Available: http://www.biol.uni.wroc.pl/cassidae/katalog\%20internetowy/ index.htm (Accessed 15 March 2011).

Ganho, N. \& R. C. Marinoni. 2000. Algumas características da reprodução e ontogênese de Epilachna paenulata (Germar) (Coleoptera, Coccicinelidae, Epilachninae). Revista Brasileira de Entomologia 17: 445-454.

Jolivet, P. \& K. K. Verma. 2002. Biology of leaf beetles. Andover, Intercept, $332 \mathrm{p}$.

Mann, J. S. \& J. P. Singh. 1979. Ovariole number in the family Chrysomelidae (Coleoptera: Phytophaga) from northern India. Journal of Entomological Research 3: 217-222.

Mann, J. S. 1988. Male genitalia of Chrysomelidae (Coleoptera) I. Subfamilies Cassidinae and Hispinae. Journal of Animal Morphology and Physiology 35: 123-130.

Robertson, J. G. 1961. Ovariole numbers in Coleoptera. Canadian Journal of Zoology 39: 245-263.

Rodriguez, V. 1994a. Sexual behavior in Omaspides convexicollis Spaeth and $O$. bistriata Boheman (Coleoptera: Chrysomelidae: Cassidinae), with notes on maternal care of eggs and young. The Coleopterists Bulletin 48: 140-144.

Rodriguez, V. 1994b. Function of the spermathecal muscle in Chelymorpha alternans Boheman (Coleoptera: Chrysomelidae; Cassidinae). Physiological Entomology 19: 198-202.

Snodgrass, R. E. 1935. Principles of insect morphology. New York, MacGraw-Hill Book Company, 667 p.

Swietojanska, J. 2001. A revision of the tribe Aspidimorphini of the Oriental Region (Coleoptera: Chrysomelidae: Cassidinae). Genus (Supplement 11). 318 p.
Received 25/3/2011; accepted 12/12/2011

Editor: Lúcia Massutti de Almeida 